\title{
Effect of the carbon nanotube basicity in Pd/N-CNT catalysts on the synthesis of R-1-phenyl ethyl acetate
}

\author{
S. Sahin ${ }^{\text {a }}$, P. Mäki-Arvela ${ }^{\text {a }}$, J.-P. Tessonnier ${ }^{\text {b }}$, A. Villa ${ }^{\text {b }}$, L. Shao ${ }^{\text {b }}$, D. S. Su ${ }^{\text {b }}$, R. Schlögl ${ }^{\text {b }}$, T. Salmi ${ }^{\text {a }}$, \\ D. Yu. Murzin ${ }^{\text {a }}$
}

${ }^{a}$ Process Chemistry Centre, Åbo Akademi University, Turku, FI-20500, Finland

${ }^{b}$ Fritz-Haber-Institut der Max-Planck-Gesellschaft, Faradagweg 4-6, 14195 Berlin, Germany

Available online 8 July 2010

\begin{abstract}
Catalytic activities of palladium catalysts supported on activated carbon and carbon nanotubes were investigated in the one-pot synthesis of $R$-1phenylethyl acetate in combination with an immobilized lipase in toluene. Palladium catalysts on carbon nanotubes with nitrogen-containing surface groups were prepared by incipient wetness impregnation. The basic N-CNT support was synthesized by post-treating oxidized CNTs in gaseous $\mathrm{NH}_{3}$ at high temperature, prior to Pd addition. The basic character of the support was adjusted by controlling the temperature of the posttreatment step. The results showed that the desired product yield was enhanced over palladium catalysts with the lowest basicity.
\end{abstract}

Keywords: one-pot cascades, carbon nanotubes, immobilized lipase, acetophenone

\section{Introduction}

Cascade methodology, implying several reactions in one reactor pot, has gained interest recently due to the savings in equipment and separation costs in particular for production of fine chemicals. One of the ways to utilize cascades efficiently is to combine biological and chemical (i.e. heterogeneous and homogeneous) catalysis [1]. Synthesis of the $R$-1-phenylethyl acetate, which is an important building block for the production of biologically active pharmaceuticals, was studied over a heterogeneous palladium (Pd) catalysts supported on carbon nanotubes (or activated carbon) in combination with an immobilized lipase in one-pot under mild reaction conditions.

Pd supported catalysts on activated carbon (AC) have been widely studied as catalysts for hydrogenation, dehydrogenation and oxidation reactions for the production of fine chemicals [2]. Activated carbons as catalyst supports present several advantages being relatively inexpensive and inert materials [3]. However, they also exhibit a major drawback as their surface properties can vary from batch to batch. Furthermore, typically Pd/AC catalysts exhibit acidic surface groups, such as carbonyl, carboxylic, phenolic hydroxyl, lactone and quinone groups [4]. It was recently reported that Brønsted acid sites enhance the hydrogenolysis of secondary alcohols, such as 1-phenylethanol, in the model reaction [5].

Carbon nanotubes (CNTs), thanks to their unique properties such as high surface area, electrical properties, high mechanical stability, and adjustable surface properties [2]. Pd has been deposited on CNTs with various methods such as incipient wetness impregnation [6], homogeneous deposition precipitation [6,7], ion exchange [6, 8] and organometallic grafting $[6,9]$. Typically, the dispersion of the metal can be improved by pre-treating the carbon nanotubes in order to introduce functional groups (e.g. oxygencontaining surface groups) to the surface to enhance interactions between the support and the catalyst precursor $[10$, $11]$.

In the present work, the catalytic activity of palladium catalysts either on activated carbon or carbon nanotubes was studied in the one-pot synthesis of $R$-1-phenylethyl acetate. The influence of the acid-base proper ties of the support on the catalytic activity has been investigated by treating oxidized CNTs with $\mathrm{NH}_{3}$ at different temperatures in order to introduce various amounts of basic $\mathrm{N}$-containing groups on the surface [12]. 
Table 1: Catalyst characterization results

\begin{tabular}{|c|c|c|c|c|}
\hline $\begin{array}{ll}\text { Entry } & \text { Catalyst }\end{array}$ & Metal dispersion (\%) & $\begin{array}{lll}\begin{array}{l}\text { Metal } \\
(\mathrm{nm})\end{array} & \text { cluster size } \\
\end{array}$ & $\operatorname{BET}\left(\mathrm{m}^{2} / \mathrm{g}_{\mathrm{Pd}}\right)$ & $\overline{\mathrm{pH}_{\text {initial }}}$ \\
\hline $1 \mathrm{Pd} / \mathrm{N}-\mathrm{CNT}^{\mathrm{a}}$ & 30 & 3.7 & 43 & 7.0 \\
\hline $2 \mathrm{Pd} / \mathrm{N}-\mathrm{CNT}^{\mathrm{b}}$ & 41 & 2.7 & 43 & - \\
\hline $3 \mathrm{Pd} / \mathrm{N}-\mathrm{CNT}^{\mathrm{c}}$ & 51 & 2.2 & 43 & 5.6 \\
\hline $4 \mathrm{Pd} / \mathrm{C}$ & 54 & 2.0 & 949 & 4.6 \\
\hline
\end{tabular}

b,c $\mathrm{CNT}$ treated with $\mathrm{NH}_{3}$ at $200{ }^{\circ} \mathrm{C}, 400{ }^{\circ} \mathrm{C}, 600{ }^{\circ} \mathrm{C}$, respectively.

Table 2: Kinetic results using Pd catalysts reduced at $200{ }^{\circ} \mathrm{C}$ for 120 min under $\mathrm{H}_{2}$ flow

\begin{tabular}{llllll}
\hline Entry Catalyst & $\begin{array}{l}\text { Initial hydrogenation rate } \\
\left(\mathrm{mmol} / \mathrm{min} / \mathrm{g}_{\text {hyd.cat. }}\right)\end{array}$ & $\begin{array}{l}\mathrm{TOF} \\
\left(\mathrm{s}^{-1}\right)\end{array}$ & $\begin{array}{l}\text { Conversion } \\
480 \mathrm{~min}(\%)\end{array}$ & $\begin{array}{l}\text { after } \\
\text { PEAc }(\%)\end{array}$ & $\begin{array}{l}\text { Selectivity } \\
\text { to }\end{array}$ \\
\hline $1 \mathrm{Pd} / \mathrm{N}-\mathrm{CNT}^{\mathrm{a}}$ & 0.002 & 0.0001 & 26 & $41^{\mathrm{d}}$ \\
$2 \mathrm{Pd} / \mathrm{N}-\mathrm{CNT}^{\mathrm{b}}$ & 0.020 & 0.0008 & 66 & $36^{\mathrm{e}}$ \\
$3 \mathrm{Pd} / \mathrm{N}-\mathrm{CNT}^{\mathrm{c}}$ & 0.030 & 0.0009 & 75 & $34^{\mathrm{e}}$ \\
$4 \mathrm{Pd} / \mathrm{C}$ & 0.10 & 0.005 & 96 & $23^{\mathrm{e}}$ \\
\hline
\end{tabular}

${ }^{\mathrm{a}, \mathrm{b}, \mathrm{c}} \mathrm{CNT}$ treated with $\mathrm{NH}_{3}$ at $200{ }^{\circ} \mathrm{C}, 400{ }^{\circ} \mathrm{C}, 600{ }^{\circ} \mathrm{C}$, respectively, ${ }^{\mathrm{d}}$ selectivity to $R$-PEAc at $26 \%$ conversion after 480 min, ${ }^{\mathrm{e}}$ selectivity to $R$ PEAc at $66 \%$ conversion.

a)

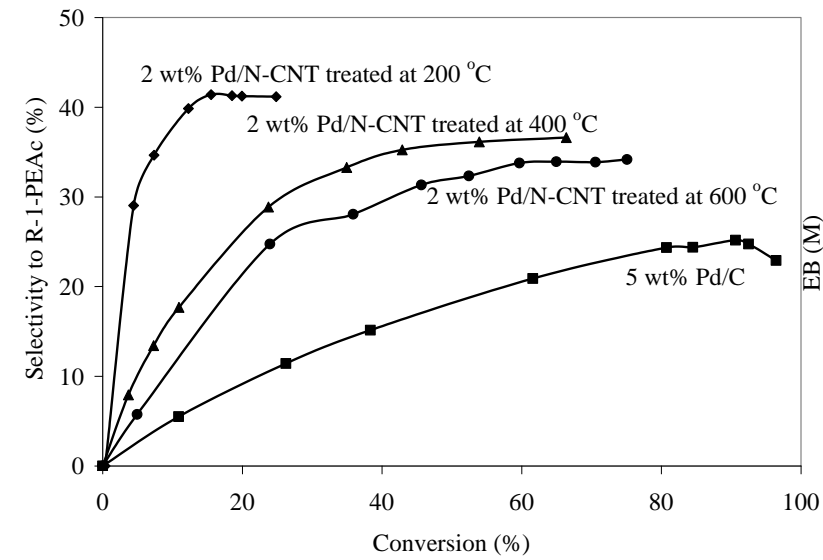

b)

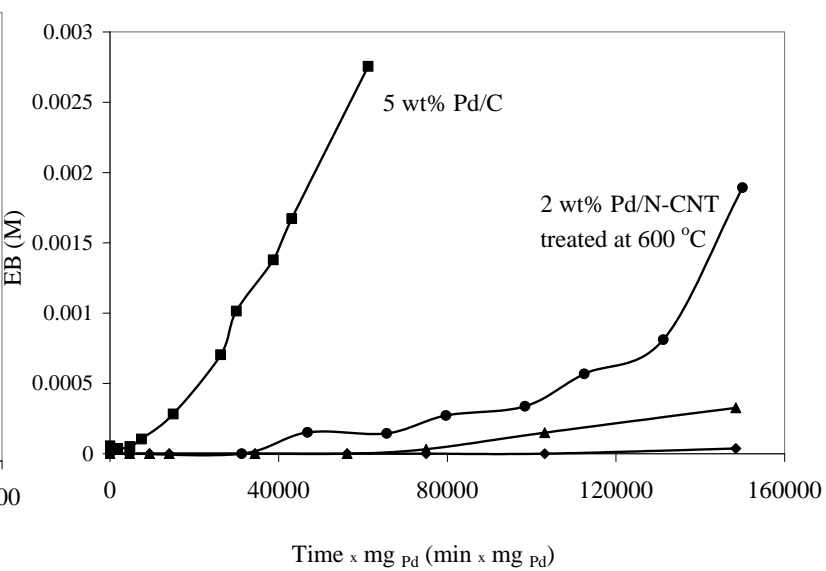

Fig. 1: a) Selectivity to $R$-PEAc as a function of acetophenone conversion, b) EB formation as a function of time.

\section{Experimental}

\subsection{Catalyst synthesis}

CNTs were first oxidized with concentrated nitric acid at $100{ }^{\circ} \mathrm{C}$ for $2 \mathrm{~h}$. After washing and drying, the oxidized CNTs were further treated with gaseous ammonia at $200{ }^{\circ} \mathrm{C}, 400{ }^{\circ} \mathrm{C}$ or $600{ }^{\circ} \mathrm{C}$, respectively [12]. $2 \%$ (w/w) $\mathrm{Pd} / \mathrm{N}-\mathrm{CNT}$ catalysts were subsequently prepared by incipient impregnation using an aqueous solution of $\mathrm{Pd}$ $\left(\mathrm{NO}_{3}\right)_{2} \cdot 2 \mathrm{H}_{2} \mathrm{O}$. After drying at room temperature for overnight, the samples were calcined in air at $350{ }^{\circ} \mathrm{C}$ for $2 \mathrm{~h}$ and reduced in hydrogen at $400{ }^{\circ} \mathrm{C}$ for $2 \mathrm{~h}$. Part of the $\mathrm{N}$ - containing basic sites was lost during the calcination and reduction. For comparison with $\mathrm{Pd} / \mathrm{N}-\mathrm{CNT}$ catalysts, $5 \%$ (w/w) Pd/AC (Degussa) was also tested.

\subsection{Experimental procedure}

Experiments were typically performed at $70{ }^{\circ} \mathrm{C}$ in toluene $(125 \mathrm{~mL})$ in a glass reactor at atmospheric pressure under $\mathrm{H}_{2}$ flow (AGA 99.999, $295 \mathrm{~mL} / \mathrm{min}$ ). The initial reactant concentration was $0.02 \mathrm{~mol} / \mathrm{L}$. Ethyl acetate with the concentration of $0.06 \mathrm{~mol} / \mathrm{L}$ was used as an acyl donor. The catalytic hydrogenation of acetophenone (Acros, 99\%) was carried out over $2 \%(\mathrm{w} / \mathrm{w}) \mathrm{Pd} / \mathrm{N}-\mathrm{CNT}(312.5 \mathrm{mg}$ ) and the formed $R$-1-phenylethanol was acylated in the same pot to $R$-1-phenylethyl acetate with an immobilized lipase (No- 
vozym 435, lipase B from Candida antarctica) $(62.5 \mathrm{mg})$. The supported Pd catalysts were pre-reduced at $200{ }^{\circ} \mathrm{C}$ prior to the experiment.

The products were analysed by a gas chromatography equipped with a chiral column CP Chirasil Dex (250 $\mu \mathrm{m} \times 0.250 \mu \mathrm{m} \times 25 \mathrm{~m})$ and a flame ionization detector. The samples were analyzed by using the flowing temperature program $100{ }^{\circ} \mathrm{C}$ (1 min)- $0.30{ }^{\circ} \mathrm{C} / \mathrm{min}-130{ }^{\circ} \mathrm{C}-15$ ${ }^{\circ} \mathrm{C} / \mathrm{min}-200{ }^{\circ} \mathrm{C}$ (10 min). The temperature of the injector and split ratio were $280{ }^{\circ} \mathrm{C}$ and $100: 1$, respectively. The products were identified with GC-MS (Agilent Technologies 6890N Network GC System, 5973 Network MS Detector).

\section{Results and discussion}

\subsection{Catalyst characterization results}

Acid-base titrations showed that during the calcination and reduction processes many basic sites were lost, thus leading to lower catalyst $\mathrm{pH}$ values for the catalysts than for the starting N-CNT supports (Table 1). This might be due to the loss of carboxylic acid groups during the catalyst preparation. The low specific area of $\mathrm{Pd} / \mathrm{N}-\mathrm{CNT}$ is due to the wall thickness of the CNTs [15]. Pd/AC exhibited the lowest $\mathrm{pH}$.

\subsection{Catalytic activity results}

Although entries 3 and 4 had similar metal particle sizes, $\mathrm{Pd} / \mathrm{AC}$, being the most active, displayed the highest turnover frequency (TOF). The relation between the TOF and the $\mathrm{pH}_{\text {initial }}$ can be seen in Table 2. The dispersions of Entries 3 and 4 were alike while the $\mathrm{pH}_{\text {initial }}$ were different, leading to a conclusion that the catalytic activity is significantly influenced by the acid-base properties of the support.

\section{References}

[1] P. Mäki-Arvela, S. Sahin, N. Kumar, J.P. Mikkola, K. Eränen, T. Salmi, D.Yu. Murzin, 2009, Catal. Today, 140, 70-73.

[2] T. Harada, S. Ikeda, M. Miyazaki, T. Sakata, H. Mori, M. Matsumura, 2007, J Mol. Catal. A: Chem., 268, 59-64.

[3] S. Wang, G.Q. Lu, 1998, Carbon, 36, 283-292.

[4] C.-C. Huang, H.-S. Li, C.-H. Chen, 2008, J Hazardous Mat., 159, 523-527.

[5] P. Mäki-Arvela, S. Sahin, N. Kumar, T. Heikkilä, V.-P. Lehto, T. Salmi, D.Yu. Murzin, 2008, J Mol. Catal. A: Chem., 285, 132-141.
The differences in activities cannot be attributed to structure sensitivity. It is well known that the maximum catalyst dispersion is favored when the carbon material is acidic [16].

The highest acetophenone conversion was obtained over $5 \%$ (w/w) Pd/AC (Entry 4). However, the yield of $R$ 1-phenylethyl acetate ( $R$-PEAc) was only $13 \%$, since ethyl benzene (EB) was formed as a major product (Entry 4) due to the acidic support (Table 2). The maximum yield of $R-1$ phenylethyl acetate over $2 \%(\mathrm{w} / \mathrm{w})$ Pd/N-CNT (Entry 3) was $26 \%$ at $75 \%$ conversion level of acetophenone corresponding to $34 \%$ selectivity over $312.5 \mathrm{mg}$ of $2 \%$ (w/w) $\mathrm{Pd} / \mathrm{N}-\mathrm{CNT}$ catalyst in combination with $62.5 \mathrm{mg}$ of immobilized lipase (Figure 1a). Furthermore, the yield of $R-1$ phenylethyl acetate as well as the conversion of acetophenone increased with an increased basicity of the support material. At the same conversion level, the most selective catalyst was $\mathrm{Pd} / \mathrm{N}-\mathrm{CNT}$ (Entry 1) in which the support was treated at $200{ }^{\circ} \mathrm{C}$ with $\mathrm{NH}_{3}$ prior to $\mathrm{Pd}$ addition exhibiting the lowest acidity of the three studied CNT-catalysts.

\section{Conclusion}

$\mathrm{Pd} / \mathrm{N}-\mathrm{CNT}$ catalysts with different surface acid/base properties were prepared. The basicity increased with increased support treatment temperature with $\mathrm{NH}_{3}$. In one-pot synthesis of $R$-1-phenylethyl acetate via hydrogenation of acetophenone over Pd/N-CNT and acylation on immobilized lipase higher acetophenone conversion was obtained with higher metal dispersion and smaller metal particle size. The yield of the desired product increased with the decreased basicity of the support material.

[6] P. Serp, M. Corrias, P. Kalck, 2003, Appl. Catal. A: Gen., 253, 337-358.

[7] M.L. Toebes, M.K. van der Lee, L.M. Tang, M.H.H. in't Veld, J.H. Bitter, A.J. van Dillen, K.P. de Jong, 2004, J Phys. Chem. B, 108 , 31, 11611-11619.

[8] M.L. Toebes, F.F. Prinsloo, J.H. Bitter, A.J. van Dillen, K.P. de Jong, 2003, J. Catal., 214, 78-87.

[9] T.G. Ros, D.E. Keller, A.J. van Dillen, J.W. Geus, D. C. Koningsberger, 2002, J. Catal., 211, 85-102. 